\title{
Aleksandra Nadgórska-Socha
}

(D) https://orcid.org/0000-0001-5073-2363

Instytut Biologii, Biotechnologii i Ochrony Środowiska, Uniwersytet Śląski

\section{Bać się czy się nie bać? Bioakumulacja, bioindykacja i toksyczność metali ciężkich Rośliny w świetle badań terenowych i laboratoryjnych}

\author{
To be afraid or not to be afraid? \\ Bioaccumulation, bioindication and toxicity of heavy metals \\ Plants in the light of field and laboratory studies
}

\begin{abstract}
Aвstract: Heavy metals that pose a threat to the environment include lead $(\mathrm{Pb})$, zinc $(\mathrm{Zn})$, copper $(\mathrm{Cu})$, arsenic $(\mathrm{As})$, cadmium $(\mathrm{Cd})$, chromium $(\mathrm{Cr})$, nickel $(\mathrm{Ni})$ and mercury $(\mathrm{Hg})$. Biomonitoring of environmental quality using plants is widely accepted as a reliable and inexpensive way of obtaining information on contamination also by heavy metals. It allows the assessment of the direction of changes in the natural environment and development of prognoses and methods for early warning related to predicted transformations in ecosystems. This paper presents the results of field and laboratory studies on floristic biodiversity in the areas of southern Poland related to extraction and processing of $\mathrm{Zn}$ and $\mathrm{Pb}$ ores. The paper also shows the selected plant defence mechanisms against the excess of heavy metals and the results of bioindication studies using different plant species, including the selected metallophytes related to the assessment of contamination levels and the most frequently used plant ecophysiological parameters. It is necessary to monitor contamination level, popularize knowledge and take action at the level of local authorities to mitigate adverse effects of human activity, bearing in
\end{abstract}


mind possible bioaccumulation of heavy metals in the food chain and the adverse health effects associated with environmental contamination.

KEY wORDs: heavy metals, biomonitoring, metallophytes, phytoremediation

\section{Wstęp}

Do metali ciężkich stanowiących zagrożenie dla środowiska biotycznego (ożywionego) i abiotycznego (nieożywionego) zaliczyć należy: ołów (Pb), cynk $(\mathrm{Zn})$, miedź $(\mathrm{Cu})$, arsen $(\mathrm{As}), \mathrm{kadm}(\mathrm{Cd})$, chrom $(\mathrm{Cr})$, nikiel $(\mathrm{Ni})$ i rtęć $(\mathrm{Hg})$ (Oyuela Leguizamo i in., 2017; Shahid i in., 2017). Określenie „biologicznie ciężki” odnosi się do metali, w niektórych przypadkach metaloidów (półmetali), które nawet $\mathrm{w}$ niskich stężeniach mogą być toksyczne dla organizmów (Walker i in., 2002; Oyuela Leguizamo i in., 2017; Briffa i in., 2020; Sayo i in., 2020). Metale ciężkie są naturalnym składnikiem środowiska, występują w skorupie ziemskiej od czasu jej powstania, a zanieczyszczeniem stają się $\mathrm{w}$ momencie przekroczenia poziomów ich naturalnych zawartości. Podstawowym źródłem zanieczyszczeń metalami są źródła naturalne (wietrzenie skał, procesy glebotwórcze, pożary lasów), a także antropogeniczne (emisja pyłów z zakładów przemysłowych, energetycznych - spalanie paliw kopalnych, ruch drogowy, nieracjonalne stosowanie nawozów mineralnych i środków ochrony roślin) (Kabata-Pendias, 2001; Siwek, 2008; Bini i in., 2012; Kutrowska, 2013; Hu i in., 2014; Simon i in., 2014; Drewnicka i in., 2016).

Zanieczyszczenie środowiska metalami śladowymi jest problemem ogólnoświatowym, wynikającym z ich bioakumulacji, czyli gromadzenia się (akumulacji) w tkankach organizmów żywych, wysokiej toksyczności oraz faktu niepodlegania degradacji biologicznej. Również ze względu na bioakumulację w łańcuchu pokarmowym pierwiastki te stanowią zagrożenie dla przyrody, w tym człowieka jako jej ważnego elementu (Massa i in., 2010; Serbula i in., 2012; Szarek-Gwiazda, 2016). Chociaż niektóre metale ciężkie, takie jak mangan $(\mathrm{Mn})$, cynk $(\mathrm{Zn})$, chrom $(\mathrm{Cr})$, miedź $(\mathrm{Cu})$, żelazo $(\mathrm{Fe})$ i nikiel $(\mathrm{Ni})$, są niezbędne dla organizmów żywych, w tym roślin, w wyższych stężeniach mogą być 
szkodliwe. Inne metale, takie jak rtęć (Hg), kadm (Cd), arsen (As) i ołów (Pb), wykazują silną toksyczność dla życia organizmów nawet przy niskich stężeniach (Shahid i in., 2017).

\section{Wybrane mechanizmy obronne roślin przed nadmiarem metali ciężkich}

Rośliny występujące na terenach $\mathrm{z}$ podwyższoną zawartością metali $\mathrm{w}$ podłożu, ale również rosnące $\mathrm{w}$ zanieczyszczonym powietrzu wykształciły szereg przystosowań do środowiska, w którym żyją. Badaniem fizjologicznych odpowiedzi roślin na warunki środowiska zajmuje się ekofizjologia roślin (Lambers i in., 2008). Mechanizmy tolerancji roślin mają za zadanie przede wszystkim skutecznie neutralizować nadmiar metali dostających się do cytoplazmy. Zapewniają one między innymi ochronę procesów metabolicznych oraz błon komórkowych przed uszkodzeniami. Polegają na produkowaniu różnych związków (między innymi glutationu, fitochelatyn, białek opiekuńczych, kwasów organicznych, aminokwasów i ich pochodnych) w odpowiedzi na pojawienie się metali $\mathrm{w}$ komórce, wiązaniu ich $\mathrm{z}$ metalami, kompartmentacji (deponowaniu kompleksów metal - biocząsteczka w miejscach mniej aktywnych metabolicznie, głównie w wakuolach i/lub w ścianie komórkowej (sekwestracja)) oraz na aktywacji systemu antyoksydacyjnego. Rośliny rozwinęły systemy usuwania i kontroli poziomu reaktywnych form tlenu (reactive oxygen species - ROS) przy użyciu nieenzymatycznych antyoksydantów, takich jak między innymi: glutation, kwas askorbinowy, karotenoidy, jak również z udziałem enzymatycznego systemu antyoksydacyjnego. Aktywność takich enzymów, jak: dysmutazy ponadtlenkowe, peroksydazy, katalazy, jest analizowana w badaniach dotyczących antyoksydacyjnej odpowiedzi obronnej na metale ciężkie (Maestri i in., 2010; Yadav, 2010; Rai, Panda, 2014; Bothe, Słomka, 2017; Shahid i in., 2017). Wiele gatunków roślin żyje w symbiozie z grzybami mikoryzowymi występującymi także na terenach zanieczyszczonych metalami ciężkimi. Grzyby te ograniczają pobieranie metali ciężkich między innymi 
dzięki wytwarzaniu przez grzybnię substancji wiążących nadmiar metali (tj. kwasy cytrynowy, szczawiooctowy, związki fenolowe) albo przez odcinanie części skażonych strzępek za pomocą systemu sept (Wójcik, Tukendorf, 1995; Pawłowska i in., 1996; Ernst, 2003; Gucwa-Przepióra i in., 2013, 2016). Każda z wymienionych odpowiedzi wywołanych stresem spowodowanym przez metale ciężkie może być traktowana jako wskaźnik ekofizjologiczny, podobnie jak roślinne zdolności bioakumulacji metali w warunkach zanieczyszczonego środowiska.

\section{Monitoring, bioindykacja, bioakumulacja metali ciężkich}

Badania biologów z ośrodków naukowych między innymi w Katowicach, Krakowie, Warszawie, Lublinie i we Wrocławiu, związane z bioindykacją terenów zanieczyszczonych i potencjalnie zanieczyszczonych przez metale, pozwalają na ocenę zagrożenia związanego z występowaniem metali ciężkich w środowisku, a w szczególności w glebie i w powietrzu. Powszechnie stosowany w nauce i praktyce termin „indykator” pochodzi od łacińskiego czasownika indicare oznaczającego 'pokazać', 'ogłosić publicznie', 'ocenić', 'nałożyć cenę'. Jest on używany $\mathrm{w}$ języku polskim wymiennie $\mathrm{z}$ równoznacznym terminem „wskaźnik” (zwanym również biowskaźnikiem lub bioindykatorem). To organizm, część organizmu lub zgrupowanie organizmów zawierające informację o stanie środowiska (Roo-Zielińska, 2004; Markert i in., 2012).

$\mathrm{Na}$ terenach, gdzie wydobywano rudy metali, dochodziło do zanieczyszczenia środowiska. Dziś obszary te porośnięte są roślinnością i niejednokrotnie zapomniano, jak były one wykorzystywane w przeszłości. Z pomocą przychodzą badania archeologów, geografów, geologów, biologów związanych z różnymi dziedzinami tych nauk, umożliwiające rozwiązanie zagadek z przeszłości w trosce o przyszłość. Przykładowo, miejsca dawnej eksploatacji rud można identyfikować metodami analizy geograficznej, co jest jednak możliwe tylko wtedy, gdy w morfologii terenu zaznaczają się antropogeniczne formy kraj- 
obrazu typu warpie, leje zapadliskowe lub składowiska odpadów (Rybak, 2002, 2004; Cabała, 2009; Rosmus, 2013) ${ }^{1}$.

Badania bioindykacyjne wykorzystujące spis gatunkowy roślin i ich pokrycie na danym obszarze pozwalają ustalić wartości wielu parametrów siedliskowych, na przykład zasobność gleb w metale ciężkie (Zimny, 2006). Diagnozowanie warunków środowiska abiotycznego na podstawie występowania określonych gatunków roślin o znanych wymaganiach ekologiczno-siedliskowych jest podstawą tworzenia tzw. skal ekologicznych liczb wskaźnikowych tych gatunków (Roo-Zielińska, 2004). Dlatego w badaniach środowiska wykorzystuje się listę ekologicznych liczb wskaźnikowych roślin, będącą zbiorem gatunków wraz z liczbami wyrażającymi reakcje danego gatunku na określony czynnik siedliskowy. W Polsce często stosuje się w tym celu opracowaną przez Zarzyckiego i współpracowników (Zarzycki i in., 2002) listę liczb wskaźnikowych dla gatunków rodzimych i w pełni zadomowionych na terenie Polski. Występowanie danego gatunku (populacji) w ekosystemie lub ograniczenie jego obecności wynika ze zmian zachodzących w środowisku w czasie i przestrzeni. Reakcja organizmów jest wypadkową wpływu mieszaniny zanieczyszczeń i zmieniających się warunków w biotopie. Monitoring biologiczny (biomonitoring) dostarcza informacji o zintegrowanym efekcie działania wszystkich czynników na organizmy żywe i może być wykorzystany do stworzenia systemu oceny oraz ostrzegania przed zagrożeniem. Monitoring środowiska ma na celu ocenę jego stanu, kierunku zmian środowiska przyrodniczego, a także opracowanie prognoz i systemu wczesnego ostrzegania o przewidywanych przeobrażeniach, ciągłe lub powtarzalne pomiary i obserwacje (Traczewska, 2011; Bąbelewska i in., 2018).

Monitorowanie jakości środowiska przy użyciu roślin jest powszechnie akceptowane również jako niezawodny i niedrogi sposób uzyskiwania informacji o zanieczyszczeniu metalami ciężkimi. Główną zaletą jest możliwość długoterminowego porównania bez potrzeby użycia kosztownego sprzętu. Takie badania

${ }^{1}$ Szczegółowe informacje na temat geologii, historii tych obszarów, funkcjonowania kopalń, także do czasów obecnych, wydobywanych rud $\mathrm{Zn}-\mathrm{Pb}$ odnaleźć można m.in. w pracach: Rybaka (2002, 2004), Cabały i Sutkowskiej (2006), Cabały (2009), Rosmusa (2013). Z danymi dotyczącymi historii olkuskiego rejonu wydobycia rud cynkowo-ołowiowych zapoznać się można m.in. w artykułach w: Godzik, red., 2015, oraz w tekście Włodarza (2020). 
biomonitoringowe obejmują analizę bioakumulacji metali w roślinach występujących na zanieczyszczonych obszarach. Wśród roślin wskaźnikowych można znaleźć także rośliny potencjalnie użyteczne w fitoremediacji - „zielonym oczyszczaniu środowiska" (Massa i in., 2010). Zanieczyszczone miejsca można uznać za rezerwuary rodzimych roślin tolerancyjnych i bioakumulujących metale ciężkie w różnych zakresach. Rodzime gatunki roślin, bardzo często ruderalne ${ }^{2}$, które pierwsze kolonizują takie tereny, mogą być cennymi bioindykatorami i bioakumulatorami metali ciężkich na tych obszarach (Massa i in., 2010). Rośliny zdolne do zasiedlania zarówno środowisk zanieczyszczonych, jak i niezanieczyszczonych metalami ciężkimi nazywane są przez biologów pseudometalofitami, w odróżnieniu od metalofitów całkowitych (obligatoryjnych), występujących tylko na terenach wzbogaconych w metale. Metalofity kolonizujące gleby bogate $\mathrm{w}$ metale ciężkie to rośliny przystosowane do wysokich stężeń takich metali, ale też do trudnych warunków edaficznych (między innymi siedlisk ubogich i termofilnych) (Grodzińska i in., 2000; Grodzińska, Szarek-Łukaszewska, 2002; Wierzbicka, Rostański, 2002; Przedpełska, Wierzbicka, 2007; Słomka i in., 2008; Nadgórska-Socha, Ciepał, 2009; Skubała, 2011; Szarek-Łukaszewska i in., 2015; Bothe, Słomka, 2017). Przeprowadzono szczegółowe badania dotyczące bioróżnorodności florystycznej na obszarach Polski południowej związanych z wydobyciem oraz przetwórstwem rud cynku i ołowiu (Olkusz, Bolesław, Chrzanów, Trzebinia, Bytom, Tarnowskie Góry). W badaniach tych wykazano, że do roślin metalolubnych spontanicznie zasiedlających składowiska odpadów cynkowo-ołowiowych w okolicach Olkusza i Bolesławia zaliczyć należy między innymi: lepnicę rozdętą (Silene vulgaris), goździka kartuzka (Dianthus carthusianorum), rzeżusznika piaskowego (Arabidopsis arenosa), przytulię białą (Galium album), macierzankę zwyczajną (Thymus pulegioides), zawciąga nadmorskiego (Armeria maritima), pleszczotkę górską (Biscutella laevigata), babkę lancetowatą (Plantago lanceolata). Analizy te dotyczyły także przystosowań wymienionych roślin do kserotermicznych i ubogich warunków środowiska. Badacze (Wierzbicka, 2002; Załęcka, Wierzbicka, 2002; Słysz, Wierzbicka, 2005;

${ }^{2}$ Rośliny ruderalne (synantropijne) to rośliny towarzyszące człowiekowi. Wyrastają w pobliżu osiedli i budowli, na poboczach dróg, śmietniskach i terenach silnie zdegradowanych (czyli na siedliskach ruderalnych). Por. https://atlas-roslin.pl/rosliny-synantropijne.htm [data dostępu: 28.02.2021]. 
Abratowska, 2006; Przedpełska, Wierzbicka 2007; Wójcik i in., 2015b; Dresler i in. 2017) wytypowali Silene vulgaris, Arabidopsis arenosa, Dianthus carthusianorum, Armeria maritima, Echium vulgare (żmijowca zwyczajnego) i Biscutella laevigata do badań mechanizmów tolerancji u roślin. Wykazali oni różnice między populacjami zasiedlającymi składowiska odpadów i tereny niezanieczyszczone. Znane są również stężenia akumulowanych przez rośliny metali z tych obszarów (Godzik, 1993; Grodzińska, Szarek-Łukaszewska, 2002; Szarek-Łukaszewska, Niklińska, 2002; Wierzbicka, Rostański, 2002; Słomka i in., 2008; Szarek-Łukaszewska, 2009; Szarek-Łukaszewska, Grodzińska, 2011; Wójcik i in., 2014; Stefanowicz i in., 2016; Woch i in., 2016). Rejony poprzemysłowe, związane z przerobem rud cynku i ołowiu (zwały, tereny narażone na imisje ${ }^{3}$ metali ciężkich), są stosunkowo trudne do skolonizowania przez gatunki roślin. Często stanowią rodzaj wyspy w otaczającym krajobrazie. Na skład flory naczyniowej na tych obszarach wpływają czynniki abiotyczne, jak: wiek urobku hałdy, długość czasu emisji metali i innych zanieczyszczeń, warunki fizykochemiczne podłoża, działania rekultywacyjne (przywrócenie wartości użytkowej glebom zniszczonym przez przemysł, czynniki biotyczne) (Harańczuk, Kompała-Bąba, 2019). Skład gatunkowy i pokrycie roślinności spontanicznie wkraczającej na składowiska odpadów cynkowo-ołowiowych są silnie zdeterminowane przez rodzaj odpadu (właściwości fizykochemiczne) oraz jego wiek. Starsze hałdy (na przykład ponad 130-letnia hałda w Bolesławiu koło Olkusza) charakteryzują się większym bogactwem gatunków i pokryciem warstwy zielnej niż hałdy, na których odpady górnicze lub hutnicze zostały zdeponowane kilkanaściekilkadziesiąt lat temu. Spośród parametrów fizykochemicznych podłoża nie zawartość metali ciężkich, ale przede wszystkim makroelementów, tj. fosforu i wapnia, ma wpływ na skład gatunkowy zbiorowisk roślinnych występujących na badanych składowiskach (Wójcik i in., 2014, 2015a).

Badania terenowe i laboratoryjne wykazały, że wiele gatunków zasiedlających zwały odpadów $\mathrm{Zn}-\mathrm{Pb}$ preferuje zasadowe $\mathrm{pH}$ podłoża. Najczęściej w glebach o $\mathrm{pH}>7$ metale ciężkie, nawet wtedy, gdy ich całkowita zawartość w glebie

${ }^{3}$ Uwalnianie zanieczyszczeń ze źródła do środowiska nazwano emisją. Natomiast pojawienie się konkretnych zanieczyszczeń w konkretnym miejscu i czasie określa się terminem „imisja”. Stężenie imisyjne to stężenie zanieczyszczenia w środowisku (Kopcewicz, Lewak, red., 2002). 
jest bardzo wysoka, występują $\mathrm{w}$ postaci nierozpuszczalnej i dlatego nie są biodostępne dla roślin. Należy jednak pamiętać, że w obrębie sfery korzeniowej, ryzosferze, gdzie zachodzą początkowe procesy mineralnego odżywiania roślin, pH jest zwykle niższe niż poza nią, co zwiększa dostępność metali toksycznych dla roślin. Wysokie stężenie metali ciężkich w glebie spowalnia również rozkład materii organicznej, obniża aktywność enzymów glebowych uczestniczących w obiegu pierwiastków, a tym samym ogranicza dostępność podstawowych składników pokarmowych (azotu i fosforu) dla roślin (Szarek-Łukaszewska, Grodzińska, 2008; Gucwa-Przepióra i in., 2016; Harańczuk, Kompała-Bąba, 2019). Biodostępność metali ciężkich zależy od form występowania metali, stężenia metali oraz ich właściwości, procesów sorpcji i desorpcji, obecności w glebie związków organicznych, potencjału oksydacyjno-redukcyjnego gleby, jej składu granulometrycznego (Wikarek-Paluch, Rosik-Dulewska, 2020). Zostały opracowane procedury chemicznej ekstrakcji z gleby frakcji potencjalnie biodostępnej w celu oszacowania prawdopodobieństwa biodostępności metali ciężkich dla roślin. Zasadniczo, w metodach tych wykorzystuje się silniejsze bądź słabsze roztwory ekstrakcyjne, zazwyczaj stosując prostą, jednostopniową ekstrakcję lub procedury sekwencjonowanej ekstrakcji do wydzielania metali ciężkich z próbek analizowanych gleb. Jednakże, mimo iż takie podejście przyczynia się do pogłębienia wiedzy na temat interakcji między metalami i komponentami gleby, rzadko można wskazać jednoznacznie, który metal w rzeczywistości oddziałuje na organizmy żywe. Oszacowanie biodostępności metali śladowych powinno być najważniejszym elementem, który pozwoliłby na ocenę potencjału roślin do uruchomienia i akumulacji metali z gleby (Branquinho i in., 2007; Remon i in., 2013). W związku z tym użycie bioindykatorów jest prostym podejściem, uzupełniającym chemiczne procedury ekstrakcji metali (Remon i in., 2013). Niektóre gatunki przystosowały się do kolonizowania obszarów o zwiększonych stężeniach metali ciężkich i stanowią tzw. florę spontaniczną. Dokładne dane - lista 145 gatunków flory naczyniowej najczęściej występujących na obszarach metalonośnych - zostały opracowane przez Rostańskiego i współpracowników (2015). Gatunki roślin zasiedlających składowiska odpadów metalonośnych, tereny wokół źródeł zanieczyszczeń metalicznych stanowiły i stanowią przedmiot badań od dziesięcioleci (Rostański, 1997; Grodzińska, Szarek-Łukaszewska, 2002; Jędrzejczyk-Korycińska, 2009; Szarek-Łukaszewska 
i in., 2015). Wśród reprezentowanych masowo na wszystkich badanych hałdach lub terenach poddanych emisjom metali ciężkich są między innymi: lepnica rozdęta (Silene vulgaris), rzeżusznik piaskowy (Arabidopsis arenosa), komonica zwyczajna (Lotus corniculatus), babka lancetowata (Plantago lanceolata), marchew zwyczajna (Daucus carota), kostrzewa owcza (Festuca ovina), rezeda żółta (Reseda lutea). Do spotykanych na takich terenach pospolitych rodzimych drzew i krzewów zaliczyć należy przykładowo: brzozę brodawkowatą (Betula pendula), topolę osikę (Populus tremula), sosnę zwyczajną (Pinus sylvestris), kalinę koralową (Viburnum opulus) i kruszynę pospolitą (Frangula alnus) (Jędrzejczyk-Korycińska, 2009; Nadgórska-Socha, 2012). Obszary takie to cenne „laboratorium biologa”, szczególnie dla osób poszukujących roślin rzadkich i chronionych różnymi formami regulacji prawnych. Wśród takich roślin potwierdzono obecność między innymi: lnicznika siewnego (Camelina sativa), wilczomlecza drobnego (Euphorbia exigua), kosaćca syberyjskiego (Iris sibirica), wyblina jednolistnego (Malaxis monophyllos), kruszczyka rdzawoczerwonego (Epipactis atrorubens), dziewięćsiła bezłodygowego (Carlina acaulis), kruszczyka szerokolistnego (Epipactis helleborine), konwalii majowej (Convallaria majalis) (Jędrzejczyk-Korycińska, 2009). Wart podkreślenia jest fakt występowania na hałdzie w Bolesławiu koło Olkusza jedynego niżowego stanowiska górskiego gatunku pleszczotki górskiej (Biscutella laevigata), reliktu glacjalnego ${ }^{4}$. Z uwagi na to obszar ten znalazł się w sieci Natura 2000. Wcześniej, w 1997 roku, został on uznany uchwałą Rady Gminy Bolesław za cenny i godny ochrony; powołano tam użytek ekologiczny (Grodzińska, Szarek-Łukaszewska, 2002; Wójcik i in., 2015a; Jędrzejczyk-Korycińska, Szarek-Łukaszewska, 2020). Zanikające murawy galmanowe $^{5} \mathrm{z}$ gatunkami metalofitów wymagają ochrony czynnej. Konieczne jest utrzymanie ich $\mathrm{w}$ dobrej kondycji, a czasem odtwarzanie na zniszczonych oraz zarośniętych przez drzewa i krzewy stanowiskach. Nadrzędnym celem

${ }^{4}$ Relikt glacjalny (polodowcowy) - organizm (takson) będący pozostałością z okresu lodowcowego. W tym czasie pewne gatunki dokonywały ekspansji na tereny położone bardziej na południe od ich zwykłego miejsca występowania (por. https://encyklopedia.biolog.pl/index. php?haslo=Relikt_glacjalny [data dostępu: 28.02.2021]).

${ }^{5}$ Murawy galmanowe - zbiorowiska roślinne charakterystyczne dla terenów z glebami metalonośnymi. 
podjętego w 2018 roku projektu „BioGalmany” jest próba odtworzenia i utrzymania odpowiednich warunków siedliskowych dla zachowania różnorodności biologicznej muraw galmanowych $\mathrm{w}$ rejonie śląsko-krakowskim, na stanowiskach chronionych w sieci Natura 2000 oraz na innych, nieobjętych dotychczas tą formą ochrony. Projekt ten dotyczy całego obszaru Pleszczotka w Bolesławiu, a także innych stanowisk muraw galmanowych rejonu śląsko-krakowskiego (Jędrzejczyk-Korycińska, Szarek-Łukaszewska, 2020).

Zachowanie bioróżnorodności metalofitów powinno stanowić kluczowy element działań ze względu na potencjalne ich wykorzystanie w metodach rekultywacji przyrodniczej. Do rekonstrukcji siedlisk zniszczonych przez metale ciężkie można zastosować metody bazujące na rodzimych, lokalnych zasobach roślin - metalofitów, spontanicznie opanowujących miejsca zdegradowane. Do przykładowych gatunków metalofitów, które wykorzystano w fitostabilizacji odpadów po flotacji rud cynku i ołowiu, należą między innymi: łyszczec baldachogronowy (Gypsophila fastigiata), driakiew żółta (Scabiosa ochroleuca), goździk kartuzek (Dianthus carthusianorum) (Muszyńska i in., 2015).

Rośliny występujące na terenach zanieczyszczonych podzielono na trzy grupy ze względu na pobieranie metali i ich dystrybucję: excluders, indicators i accumulators (Baker, 1981). Pierwsza grupa roślin, tzw. wykluczających, pobiera lub zatrzymuje większość metalu w korzeniach i ogranicza jego translokację do organów nadziemnych. Druga grupa to rośliny wskaźnikowe (indicators). Pobierają one metale proporcjonalnie do ich zawartości w podłożu i gromadzą je dość równomiernie w tkankach korzeni oraz części nadziemnych. Natomiast trzecia grupa, tzw. akumulatory (accumulators), to rośliny, które pobierają duże ilości metali z podłoża i transportują je do organów nadziemnych. Niektóre akumulatory to hiperakumulatory, które są zdolne do akumulacji ponadprzeciętnie wysokich stężeń metali (powyżej $1 \% \mathrm{Zn}$ lub Mn; 0,1\% Ni, Pb, Cu, Co, Cr; 0,01\% Cd w suchej masie organów nadziemnych) (Wójcik i in., 2015a).

W prowadzonych badaniach w sąsiedztwie Huty Cynku „Miasteczko Śląskie”, byłej Huty Metali Nieżelaznych „Szopienice”, na terenach po wydobyciu

${ }^{6}$ Szczegółowych informacji dotyczących muraw galmanowych, ich bioróżnorodności oraz projektu „BioGalmany” dostarczyć może publikacja: Jędrzejczyk-Korycińska, Szarek-Łukaszewska, 2020. 
rud metali w Bolesławiu i Dąbrowie Górniczej wskazano, że rzeżusznik piaskowy (Arabidopsis arenosa) w przypadku Zn i Cd wykazuje strategię akumulacji. Stężenia $\mathrm{Cd}$ i $\mathrm{Zn}$ w liściach $A$. arenosa miały wartości wyższe niż uznane za toksyczne, czyli 100-400 mg/kg Zn, 5-30 mg/kg Cd (według: Kabata-Pendias, 2001; Massa i in. 2010). W liściach A. arenosa zbieranych w Bolesławiu wykryto również stężenie Cd (100,2 mg/kg s.m.) podobne do proponowanego dla hiperakumulatorów. Z kolei babka lancetowata (Plantago lanceolata) i babka zwyczajna (P. major) wykazywały strategię unikania w przypadku $\mathrm{Zn}, \mathrm{Pb}$ oraz $\mathrm{Cd}$ (Nadgórska-Socha i in., 2015). Także badania Gieroń i współpracowników (2021) na 14 europejskich obszarach niezanieczyszczonych i zanieczyszczonych, w tym w Polsce (Bukowno, Klucze, Katowice-Szopienice, Katowice-Wełnowiec, Dołki, Piekary Śląskie), pokazały, że populacje rzeżusznika piaskowego (Arabidopsis arenosa) z terenów metalonośnych wykazują cechy hiperakumulacji Zn i rzadziej Cd. W badaniach Wójcik i współpracowników (2014) przeprowadzonych na roślinności hałdowej $\mathrm{z}$ trzech składowisk odpadów cynkowo-ołowiowych w Piekarach Śląskich, Brzezinach Śląskich i Bolesławiu nie stwierdzono jednocześnie obecności hiperakumulatorów ani roślin o dużej biomasie, dlatego żaden z tamtejszych gatunków nie może być użyteczny w procesie fitoekstrakcji Nie stwierdzono też gatunków wskaźnikowych. Natomiast określenie średniego stężenia metali $\mathrm{w}$ organach nadziemnych wszystkich roślin tworzących zbiorowiska na danym obszarze może być przydatne w biomonitoringu terenów zanieczyszczonych metalami, ponieważ bardzo dobrze oddaje zawartości metali w podłożu, niezależnie od wieku i rodzaju odpadu. Ze względu na często występującą strategię wykluczania pseudometalofity spotykane na terenach metalonośnych można wykorzystać przede wszystkim do fitostabilizacji ${ }^{8}$, co

${ }^{7}$ Fitoekstrakcja jest techniką stosowaną w oczyszczaniu gleb i osadów skażonych metalami ciężkimi oraz materiałami radioaktywnymi. W tej technice fitoremediacyjnej wykorzystuje się rośliny akumulujące metale ciężkie w swych nadziemnych częściach, które po okresie wegetacji z oczyszczanego terenu usuwa się.

${ }^{8}$ Fitostabilizacja polega na zasiedlaniu terenów skażonych przez rośliny tolerujące wysokie stężenia metali (metal excluders). Technika ta nie pozwala na usuwanie zanieczyszczeń ze środowiska, ale na zmniejszenie ich mobilności, tym samym ograniczając przemieszczanie się toksycznych związków w głąb profilu glebowego oraz w formie pyłów do atmosfery (Muszyńska i in., 2020). 
potwierdzają również badania Harańczuka i Kompały-Bąby (2019) w Żabich Dołach na granicy miast: Bytomia, Chorzowa i Piekar Śląskich. Wykazane pseudometalofity: mietlica pospolita (Agrostis capillaris), rzeżusznik piaskowy (Arabidopsis arenosa), marchew zwyczajna (Daucus carota), śmiałek darniowy (Deschampsia caespitosa), brodawnik zwyczajny (Leontodon hispidus), babka lancetowata (Plantago lanceolata), lepnica rozdęta (Silene vulgaris) i szczaw zwyczajny (Rumex acetosa), rozwinęły strategię wykluczania metali, dlatego mogą znaleźć zastosowanie w pracach rekultywacyjnych zwałów poflotacyjnych $\mathrm{Zn}-\mathrm{Pb}$. W badaniach wykorzystywano także wybrane populacje lepnicy rozdętej (Silene vulgaris) (najbliższe sąsiedztwo Huty Metali Nieżelaznych „Szopienice” w Katowicach w odległości 50, 250, $450 \mathrm{~m}$ od emitora, była hałda odpadów pohutniczych w Katowicach-Wełnowcu, obszar po wydobyciu złóż cynkowo-ołowiowych w Dąbrowie Górniczej). Celem była ocena in situ (bezpośrednio $\mathrm{w}$ terenie poprzemysłowym) potencjału fitoekstrakcyjnego $\mathrm{Zn}, \mathrm{Pb}$ i $\mathrm{Cd}$. Stężenie Cd w częściach nadziemnych badanego gatunku mieściło się w zakresie 7-87 mg/kg, Pb - 35-262 mg/kg, Zn - 1875-8316 mg/kg. Największą biomasę wykazały rośliny w odległości $450 \mathrm{~m}$ od emitora (194 kg s.m./ha). Również oszacowany poziom fitoekstrakcji obliczony dla $S$. vulgaris in situ był najwyższy w odległości $450 \mathrm{~m}$ od emitora (1119 g/ha Zn, 11 g/ha Pb, 6 g/ha Cd). Ze względu na wysokie zdolności do gromadzenia metali $S$. vulgaris to odpowiedni gatunek do budowania pokrywy roślinnej terenów zanieczyszczonych przez metale ciężkie. Dodatkowo, stężenia Zn wykazane w nadziemnych częściach tego pseudometalofita wydają się istotne w procesie fitoekstrakcji (Nadgórska-Socha, Ciepał, 2009).

Prowadzono również badania dotyczące akumulacji wybranych metali ciężkich i odpowiedzi ekofizjologicznej u gatunków roślin, tj. borówki czarnej (Vaccinium myrtillus), borówki czerwonej (Vaccinium vitis-idaea) oraz sosny zwyczajnej (Pinus sylvestris), występujących pospolicie w borach sosnowych, także na terenach zanieczyszczonych (między innymi w sąsiedztwie Huty Cynku „Miasteczko Śląskie”, huty ArcelorMittal Poland w Dąbrowie Górniczej, Elektrowni Jaworzno III). Co ciekawe, obydwa wymienione gatunki borówki wykazywały strategię wykluczania $\mathrm{Cd}, \mathrm{Pb}, \mathrm{Zn}$ i Fe. W przypadku Mn wskaźnik translokacji $(T F)$, mobilności $(M R)$ oraz wskaźnik biokoncentracji $(B C F)$ dla większości populacji był większy niż 1, co potwierdza szczególną zdol- 
ność $V$. myrtillus do akumulacji tego pierwiastka w częściach nadziemnych (Kandziora-Ciupa i in., 2013). Badania kumulacji metali ciężkich w roślinach wybranych gatunków terenów chronionych województw śląskiego i małopolskiego wykazały, że zawartość metali ciężkich w tych roślinach jest dobrym oraz porównywalnym kryterium oceny wpływu zanieczyszczeń powietrza, a najlepszym miernikiem tego wpływu jest ocena zmian stężeń metali w pełnym układzie: atmosfera - gleba - roślina (Ciepał, 1999).

Do bardzo dobrych wskaźników zanieczyszczenia powietrza należą porosty. Znając tolerancję niektórych gatunków na określone stężenia $\mathrm{SO}_{2}$, skonstruowano skalę porostową, za pomocą której można oszacować stopień skażenia powietrza (według: Zimny, 2006; Fojcik, 2013; Fałtynowicz, 2014). Porosty znalazły zastosowanie także $\mathrm{w}$ badaniach zanieczyszczenia środowiska metalami ciężkimi. W programach: „D1. Metale ciężkie i siarka w porostach” oraz „M1. Epifity nadrzewne” Zintegrowanego Monitoringu Środowiska Przyrodniczego, funkcjonującego w ramach Państwowego Monitoringu Środowiska, porosty są używane do oceny jakości środowiska. Stosując porosty $\mathrm{w}$ biomonitoringu, wybiera się się zarówno metodę ich zbioru in situ, jak i metodę ich transplantacji na obszary, w których naturalnie nie występują ze względu na wysokie stężenia zanieczyszczeń gazowych lub niekorzystne warunki środowiskowe (Sawicka-Kapusta i in., 2018). Zwykle w badaniach wykorzystywany jest gatunek porostów pustułka pęcherzykowata (Hypogymnia physodes). Metoda transplantacji polega na przenoszeniu dobrze wykształconych plech listkowatej pustułki pęcherzykowatej na obszar, który będzie monitorowany, a następnie, po określonym czasie ekspozycji (3-6 miesięcy), na rejestrowaniu zmian w morfologii, anatomii, chemizmie plech (Fałtynowicz, 2014). Metoda badań in situ, a także transplantacji, jest wykorzystywana między innymi w Zintegrowanym Monitoringu Środowiska Przyrodniczego w programie „Zawartość metali ciężkich i siarki w porostach”. Badania in situ prowadzono na terenie następujących Stacji Bazowych: Puszcza Borecka, Wigry, Storkowo, Kampinos, Św. Krzyż, Szymbark, Wolin, Roztocze. Natomiast na terenie stacji Św. Krzyż, Szymbark oraz Koniczynka, gdzie pustułka naturalnie nie występuje, przywiezione plechy porostów z terenu niezanieczyszczonego z Borów Tucholskich, transplantowano. Szczegóły badań zawartości metali ciężkich i siarki w plechach Hypogymnia physodes i w plechach po sześcio- 
miesięcznej ekspozycji przedstawiono w obszernym opracowaniu Sawickiej-Kapusty i współpracowników (2018).

Obok porostów najczęściej wykorzystywanymi organizmami do oceny zanieczyszczenia powietrza są mchy. Badania bioindykacyjne przy ich użyciu zostały zapoczątkowane pod koniec lat 60. XX wieku przez Rühlinga i Tylera (1968). Ta klasa mszaków uważana jest obecnie za jeden z najlepszych biowskaźników zanieczyszczeń powietrza metalami śladowymi i wielopierścieniowymi węglowodorami aromatycznymi. Mimo że mchy są pozbawione korzeni, to substancje odżywcze oraz zanieczyszczenia pobierają całą swoją powierzchnią z mokrej bądź suchej depozycji atmosferycznej (Świsłowski i in., 2017). Na terenie Katowic prowadzono badania dotyczące epifitycznych gatunków mchów $\mathrm{w}$ środowisku miejskim. Celem badań była ocena poziomu zanieczyszczenia stanowisk $\mathrm{z}$ epifitami i bez epifitów, stopnia kolonizacji różnych gatunków drzew przez epifity oraz stężenia wybranych metali w mchach i w korze drzew. Wykazano, że do najczęściej kolonizowanych gatunków drzew zaliczyć należy topole oraz wierzby, posiadające wyższe $\mathrm{pH}$ kory niż inne gatunki. Pokazano, że rozmieszczenie epifitycznych gatunków mchów (rodzaj Orthotrichum i Ulota) w środowisku miejskim Katowic zależy od takich czynników, jak: obecność odpowiedniego gatunku drzewa, chemizm kory (biorąc pod uwagę wpływ czynników naturalnych i antropogenicznych), wilgotność i poziom skażenia powietrza (Fojcik i in., 2017). Zanieczyszczenie pyłem $\mathrm{PM}_{2,5}{ }^{9} \mathrm{w}$ miastach województwa śląskiego jest podobne jak w Krakowie, ale niższe niż w miastach Azji, gdzie stwierdza się największe na świecie zanieczyszczenie powietrza. Warto jednak pamiętać, że z pyłami $\mathrm{PM}_{2,5}$ mogą adsorbować, łączyć się i transportować wielopierścieniowe węglowodory aromatyczne (WWA), polichlorowane bifenyle (PCB), metale ciężkie, bakterie, wirusy oraz inne toksyczne substancje i potencjalne czynniki rakotwórcze. $\mathrm{PM}_{2,5}$ zawiera zanieczyszczenia

${ }^{9}$ Wyróżnia się cztery frakcje pyłu: TSP (Total Suspended Particulates) - całkowity pył zawieszony; $\mathrm{PM}_{10}$ - pył inhalacyjny o średnicy mniejszej niż $10 \mu \mathrm{m} ; \mathrm{PM}_{2,5}$ - pył respirabilny o średnicy mniejszej niż 2,5 $\mu \mathrm{m} ; \mathrm{PM}_{0,1}$ - pył o średnicy poniżej 0,1 $\mu \mathrm{m}$ (Rogala i in., 2015; Juda-Rezler, Toczko, red., 2016). Szczegółowe informacje dotyczące właściwości pyłów, rozprzestrzeniania, oddziaływania na środowisko, modelowania pyłowego zanieczyszczenia atmosfery, stanu zanieczyszczenia powietrza w Polsce przez pył zawieszony odnaleźć można w publikacji Judy-Rezler i Toczko (red., 2016). 
takie jak: siarczan, azotany i węgiel, które wnikają głęboko do płuc i układu sercowo-naczyniowego, stwarzając największe zagrożenie dla zdrowia ludzkiego (Nadgórska-Socha i in., 2017). Zbadano skład pierwiastkowy cząstek pyłu osadzonego na dolnych powierzchniach liści dwóch gatunków babki: lancetowatej i zwyczajnej - materiał roślinny pobierano z terenu Rudy Śląskiej. Mikroanaliza rentgenowska wykazała obecność $\mathrm{Si}, \mathrm{Fe}, \mathrm{S}, \mathrm{Na}, \mathrm{Ca}, \mathrm{Mg}, \mathrm{Cl}, \mathrm{O}, \mathrm{K}$ i Al na całym badanym odcinku powierzchni liścia. Najwyższe ilości Si i Al odnotowano na liściach roślin rosnących przy drodze i narażonych przez to na emisję pyłu, a wyższą zawartość Fe i Mn oraz zarodników grzybów na liściach obu gatunków występujących w sąsiedztwie zakładu metalurgicznego (Skrynetska i in., 2019). Narażone na zanieczyszczenia rośliny ze środowiska miejskiego wykazują zróżnicowane odpowiedzi w przebiegu procesu fotosyntezy, oddychania, reakcji enzymatycznych, w funkcjonowaniu aparatów szparkowych, równowadze błon komórkowych. W celu określenia tolerancji bądź wrażliwości roślin na zanieczyszczenia powietrza wykorzystywane są badania różnych parametrów fizjologicznych, tj. zawartości chlorofilu, kwasu askorbinowego, względnej zawartości wody (RWC), pH ekstraktu liści, które zostały połączone, aby oszacować Indeks Tolerancji Zanieczyszczenia Powietrza (APTI - Air Pollution Tolerance Index). Dzięki wskaźnikowi APTI można wskazywać gatunki roślin odpornych na zanieczyszczenia środowiska miejskiego. Pomiary APTI wykorzystuje się w badaniach drzew i krzewów oraz roślin zielnych (Nadgórska-Socha i in., 2016, 2017). Ze względu na to, że wrażliwość i odpowiedź roślin na skażenia powietrza różnią się, gatunki roślin, które są bardziej wrażliwe, mogą znaleźć zastosowanie jako bioindykatory zanieczyszczeń powietrza, w tym także metali ciężkich, natomiast gatunki tolerancyjne zgodnie ze wskaźnikiem APTI mogą być przydatne do właściwego planowania pasów zieleni. Denaturacja chlorofilu, rozpad barwników chlorofilowych stanowią wymierną odpowiedź roślin na stresowe warunki. Większa zawartość wody u roślin pomaga w utrzymaniu ich równowagi biochemicznej i fizjologicznej w warunkach zanieczyszczenia. Wysokie $\mathrm{pH}$ pomaga $\mathrm{w}$ zamianie cukrów sześciowęglowych $\mathrm{w}$ kwas askorbinowy, antyutleniacz uczestniczący w usuwaniu reaktywnych form tlenu (ROS). Zwiększone stężenie kwasu askorbinowego u roślin pomaga pokonywać stres związany z zanieczyszczeniami. W miejscach skażonych zaobserwowano wysokie stężenie tego związku w porównaniu do jego stężeń wykazywanych u roślin 
$\mathrm{z}$ terenu kontrolnego. Kwas askorbinowy odgrywa ważną rolę w mechanizmie obronnym i uczestniczy w wielu reakcjach fizjologicznych (Nadgórska-Socha i in., 2016, 2017; Skrynetska i in., 2018, 2019). Kwaśny zakres pH wodnego ekstraktu z liści roślin $\mathrm{z}$ terenów zanieczyszczonych jest wynikiem oddziaływania na rośliny $\mathrm{SO}_{2}$ i $\mathrm{NO}_{2} \mathrm{z}$ atmosfery. Wrażliwe rośliny szybciej zamykają aparaty szparkowe, kiedy są narażone na skażenia powietrza. Neutralne $\mathrm{pH}$ (tj. około 7) ekstraktu z liści było charakterystyczne raczej dla drzew bardziej tolerancyjnych niż drzew o odczynie kwaśnym. Prowadzono badania dotyczące bioakumulacji metali ciężkich i wskaźnika APTI u czterech gatunków roślin - dwóch zielnych: mniszka pospolitego (Taraxacum officinale) i babki lancetowatej (P. lanceolata), oraz dwóch gatunków drzew: robinii akacjowej (Robinia pseudoacacia) i brzozy brodawkowatej (Betula pendula), w wybranych dziesięciu biotopach jednego z najbardziej zanieczyszczonych miast Polski - Dąbrowy Górniczej. Wykazane stężenia $\mathrm{Fe}, \mathrm{Zn}, \mathrm{Pb}$ i Cd w liściach roślin były bardziej zróżnicowanie niż $\mathrm{Cu}$ i Mn. To sugeruje, że poziom tych pierwiastków wiązał się bardziej z lokalną aktywnością przemysłową i ruchem samochodowym (Kováčik i in., 2016). Uzyskane zakresy stężeń pierwiastków w liściach badanych roślin porównano z uznanymi za referencyjne - dla „rośliny referencyjnej” pochodzącej z niezanieczyszczonego środowiska (reference plant) według Markerta (1992) wartości te to: $50 \mathrm{mg} / \mathrm{kg} \mathrm{Zn,} 1 \mathrm{mg} / \mathrm{kg} \mathrm{Pb}, 0,05 \mathrm{mg} / \mathrm{kg} \mathrm{Cd}, 10 \mathrm{mg} / \mathrm{kg} \mathrm{Cu}, 150 \mathrm{mg} / \mathrm{kg} \mathrm{Fe}$ i $200 \mathrm{mg} / \mathrm{kg} \mathrm{Mn}$. Wartości referencyjne mogą być uznane za stężenia fizjologiczne na poziomie tła geochemicznego i stanowić przedział zróżnicowania biologicznego $\mathrm{w}$ roślinnym chemicznym odcisku palca (plant chemical fingerprint $)^{10}$ (Markert, 1992; Djingova i in., 2004). Porównanie uzyskanych wyników z wartościami stężeń pierwiastków dla „rośliny referencyjnej” może stanowić szybką ocenę poziomu zanieczyszczenia i ekologicznego zagrożenia ekosystemu. Badania te ściśle potwierdziły zanieczyszczenie miasta $\mathrm{Zn}, \mathrm{Pb}, \mathrm{Cd}$ i Fe na powierzchniach związanych z przemysłem, ruchem samochodowym oraz na terenie rekreacyjnym w sąsiedztwie zbiornika Pogoria III. Wykazano również, że rośliny ze wskaźnikiem APTI większym niż 17 - B. pendula i T. officina-

${ }^{10}$ Chemiczny odcisk palca to kompleksowy, charakterystyczny profil chemiczny roślin lub produktów roślinnych, np. ziołowych, który może być zastosowany w celu oceny ich jakości. 
le - mogą stanowić naturalną barierę $\mathrm{w}$ walce $\mathrm{z}$ zanieczyszczeniem atmosfery w biotopach miejskich (Nadgórska-Socha i in., 2017).

\section{Biologiczne badania w trosce o jakość środowiska i zdrowie człowieka - podsumowanie}

$\mathrm{Na}$ podstawie badań bioindykacyjnych możliwe jest określenie poziomu zanieczyszczenia środowiska, w tym przez metale ciężkie. Czy zatem wiedząc o stwierdzonych stężeniach zanieczyszczeń, powinniśmy się bać otaczającej nas przyrody? Rośliny rosnące $\mathrm{w}$ zanieczyszczonym środowisku mogą gromadzić toksyczne metale $\mathrm{w}$ wysokim stężeniu, stwarzając poważne ryzyko dla zdrowia ludzkiego w sytuacji ich spożycia. Może to dotyczyć także roślin i wytwarzanych z nich produktów stosowanych do celów medycznych. Dlatego ważne jest, aby monitorować jakość żywności, biorąc pod uwagę, że pobieranie metali przez rośliny jest jednym z głównych szlaków, przez które metale ciężkie wchodzą do łańcucha pokarmowego (Romeh, 2017). Stąd badania ryzyka zdrowotnego (health risk assessment) oparte na szacowaniu health risk index (HRI syn. THQ - Target hazard quotient). Wskaźnik zagrożenia zdrowia/iloraz zagrożenia służy do oceny potencjalnych i niekorzystnych skutków zdrowotnych spożycia na przykład ziół, ale i warzyw, owoców z terenów zanieczyszczonych (Romeh, 2017; Pehoiu i in., 2020). Dzięki szczegółowym badaniom zawartości metali w glebach użytkowanych rolniczo na terenach zanieczyszczonych: gleb ogródków działkowych, ogrodów przydomowych, a także zlokalizowanych na obrzeżach miast aglomeracji śląskiej pól uprawnych, możliwe było określenie, czy skażenie gleb Górnego Śląska metalami ciężkimi jest problemem przeszłości, czy stanowi aktualne zagrożenie. Wykazano zróżnicowane zanieczyszczenie metalami ciężkimi i mimo ograniczenia emisji metali do środowiska niektóre gleby zawierały bardzo wysokie stężenia $\mathrm{Cd}, \mathrm{Zn}$ i $\mathrm{Pb}$. W związku z tym na terenach skażonych metalami należy podjąć działania służące ograniczeniu narażenia społeczeństwa - zaprzestać spożycia lokalnie uprawianych warzyw (Dziubanek i in., 2012). 
Miejskie tereny zielone są korzystne dla dobrobytu społecznego, gdyż pozwalają zwiększyć spójność społeczną i identyfikację z lokalnym obszarem. Mogą pozytywnie wpływać na zdrowie psychiczne, obniżając negatywne emocje (Bertram, Rehdanz, 2015). Jednocześnie mogą one pochłaniać/akumulować zanieczyszczenia. Miejska zieleń urządzona składa się często z gatunków obcego pochodzenia i ograniczona jest głównie do pielęgnowanych terenów miejskich. W miastach oprócz takiej „wymuskanej” zieleni dużą rolę odgrywa roślinność porastająca teren w sposób spontaniczny, przy większym lub mniejszym współudziale roślinności półnaturalnej, naturalnej oraz synantropijnej. Warto zwrócić uwagę na fakt, że właśnie roślinność spontaniczna odgrywa ważną rolę w funkcjonowaniu całych biocenoz ${ }^{11}$, między innymi w utrzymaniu wielu gatunków zwierząt, dając im schronienie i miejsce żerowania. W ostatnim czasie akceptacja i wykorzystanie roślinności spontanicznej są bardzo silnie propagowane w planowaniu terenów zieleni miejskiej (Wysocki, 2019).

Wiedzę na temat jakości środowiska w miastach, gdzie ludzie spędzają większość czasu, można zdobyć dzięki określonym gatunkom roślin, które przede wszystkim występują w środowisku miejskim spontanicznie. Są najlepiej przystosowane do panujących warunków, stanowią źródło materiału genetycznego form optymalnie przystosowanych do wzrostu na podłożu z często toksyczną dla innych roślin zawartością metali. Roślinność ta dzięki określonym właściwościom zabezpiecza przed pyłem oraz łączącymi się z nim toksycznymi pierwiastkami i związkami. Dlatego, aby ograniczyć zagrożenia związane z metalami ciężkimi, potrzebne są badania terenowe i laboratoryjne dostarczające informacji o jakości środowiska oraz tolerancji roślin na badane zanieczyszczenia. Potrzebne są również działania edukacyjne upowszechniające wiedzę na temat unikalnych, także tych spontanicznych, towarzyszących człowiekowi roślin i ich zbiorowisk, porastających tereny poprzemysłowe. A zatem, aby nie bać się otaczającej nas przyrody, należy przede wszystkim monitorować poziom zanieczyszczeń, popularyzować wiedzę, a następnie na poziomie władz lokalnych podejmować działania zmierzające do łagodzenia negatywnych skutków

${ }^{11}$ Biocenoza - ożywiona część ekosystemu obejmująca wszystkie populacje i gatunki organizmów zwierzęcych i roślinnych oraz mikroorganizmów, które zasiedlają określony biotop. 
działalności człowieka. Często warto też pozwolić przyrodzie na samoczynne naprawianie wyrządzonych przez nasz gatunek szkód.

\section{Bibliografia}

Abratowska A., 2006: Armeria maritima - gatunek roślin przystosowany do wzrostu na glebach skażonych metalami ciężkimi. „KOSMOS. Problemy nauk biologicznych”, T. 55 , nr 2-3, s. 217-227.

Baker A., 1981: Accumulators and Excluders - Strategies in the Response of Plants to Heavy Metals. "Journal of Plant Nutrition", Vol. 3, s. 643-654.

Baker A., Ernst W., Van der Ent A., Malaisse F., Ginocchio R., 2010: Metallophytes: The Unique Biological Resource, Its Ecology and Conservational Status in Europe, Central Africa and Latin America. In: Ecology of Industrial Pollution. Eds. L.C. Batty, K.B. Hallberg. Cambridge University Press, Cambridge, s. 7-40.

Bąbelewska A., Musielińska R., Ciesielski W., 2018: Bioindykacyjna ocena stopnia zagrożenia metalami ciężkimi zbiorowisk leśnych Załęczańskiego Parku Krajobrazowego przy wykorzystaniu zdolności kumulacji plech porostu Hypogymnia physodes L. „Prace Naukowe Akademii im. Jana Długosza w Częstochowie. Technika, Informatyka, Inżynieria Bezpieczeństwa", T. 6, s. 479-496. https://doi.org/10.16926/ tiib.2018.06.35.

Bertram C.H., Rehdanz K., 2015: The Role of Urban Green Space for Human Wellbeing. "Ecological Economics", Vol. 120, s. 139-152. https://doi.org/10.1016/j. ecolecon.2015.10.013.

Bini C., Wahsha M., Fontana S., Maleci L., 2012: Effects of Heavy Metals on Morphological Characteristic of Taraxacum officinale Web Growing on Mine Soils in NE Italy. "Journal of Geochemical Exploration", Vol. 123, s. 101-108. https://doi.org/10.1016/j. gexplo.2012.07.009.

Bothe H., Słomka A., 2017: Divergent Biology of Facultative Heavy Metal Plants. "Journal of Plant Physiology", Vol. 219, s. 45-61. https://doi.org/10.1016/j.jplph.2017.08.014.

Branquinho C., Serrano H., Pinto M., Martins-Loução M., 2007: Revisiting the Plant Hyperaccumulation Criteria to Rare Plants and Earth Abundant Elements. "Environmental Pollution", Vol. 146, Issue 2, s. 437-443. https://doi.org/10.1016/j. envpol.2006.06.034. 
Briffa J., Sinagra E., Blundell R., 2020: Heavy Metal Pollution in the Environment and Their Toxicological Effects on Humans. "Heliyon", Vol. 6, Issue 9, e04691. https:// doi.org/10.1016/j.heliyon.2020.e04691.

Cabała J., 2009: Metale ciężkie w środowisku glebowym olkuskiego rejonu eksploatacji rud $\mathrm{Zn}-\mathrm{Pb}$. Wydawnictwo Uniwersytetu Śląskiego, Katowice.

Cabała J., Sutkowska K., 2006: Wptyw dawnej eksploatacji i przeróbki rud Zn-Pb na skład mineralny gleb industrialnych, rejon Olkusza i Jaworzna. „Prace Naukowe Instytutu Górnictwa Politechniki Wrocławskiej. Studia i Materiały”, Vol. 117, nr 32, s. $13-22$.

Ciepał R., 1999: Kumulacja metali ciężkich i siarki w roślinach wybranych gatunków oraz glebie jako wskaźnik stanu skażenia środowiska terenów chronionych województw ślaskiego i małopolskiego. Wydawnictwo Uniwersytetu Śląskiego, Katowice.

Djingova R., Kuleff I., Markert B., 2004: Chemical Fingerprint of Plants. "Ecological Research", Vol. 19, Issue 1, s. 3-11. https://doi.org/10.1111/j.1440-1703.2003.00602.x.

Dmuchowski W., 2005: Use of Plant Bioindicators in Assessment of Environmental Contamination with Heavy Metals. "Reports of the Botanical Garden of the 176 Polish Academy of Sciences, Series: Monographs and Treatises", Vol. 7, s. 1-116.

Dresler S., Rutkowska E., Bednarek W., Stanisławski G., Kubrak T., Bogucka-Kocka A., Wójcik M., 2017: Selected Secondary Metabolites in Echium vulgare L. Populations from Nonmetalliferous and Metalliferous Areas. "Phytochemistry", Vol. 133, s. 4-14. https://doi.org/10.1016/j.phytochem.2016.11.001.

Drewnicka K., Cetnarska E., Cąkała Z., Bugaj E., 2016: Porównanie akumulacji metali ciężkich - $\mathrm{Zn}$, Cr i Pb w liściach brzozy brodawkowej (Betula verrucosa) z terenu Wyżyny Krakowsko-Częstochowskiej i Pojezierza Mazurskiego. „Analit”, nr 1, s. 2-5.

Dziubanek G., Baranowska R., Oleksiuk K., 2012: Metale ciężkie w glebach Górnego Śląska - problem przeszłości czy aktualne zagrożenie? "Journal of Ecology and Health", R. 16, nr 4, s. 169-176.

Ernst W.H.O., 2003: Evolution of Adaptation Mechanisms of Plants on Metal-Enriched Soils. In: Physiological Plant Ecology. Ecophysiology and Stress Physiology of Functional Group. Ed. W. Larcher. Springer-Verlag, Berlin-Heidelberg-New York, s. $433-436$.

Fałtynowicz W., 2014: Porosty jako biowskaźniki zmian w środowisku Karkonoszy. Jelenia Góra. Wydawnictwo Karkonoskiego Parku Narodowego, Jelenia Góra.

Fojcik B., 2013: Bioindykacja i biomonitoring - czyli bajki $z$ mchu i paproci inaczej. W: Problemy środowiska i jego ochrony. Red. A. Babczyńska, M. Nakonieczny. Centrum Studiów nad Człowiekiem i Środowiskiem, Uniwersytet Śląski, Katowice, s. 45-56. 
Fojcik B., Chruścińska M., Nadgórska-Socha A., 2017: Epiphytic Habitats in an Urban Environment; Contamination by Heavy Metals and Sulphur in the Barks of Different Tree Species. "Polish Journal of Natural Sciences", no 32 (2), s. 283-295.

Gieroń Ż., Sitko K., Zieleźnik-Rusinowska P., Szopiński M., Rojek-Jelonek M., Rostański A., Rudnicka M., Małkowski E., 2021: Ecophysiology of Arabidopsis arenosa, a New Hyperaccumulator of Cd and Zn. "Journal of Hazardous Materials", Vol. 412, 125052. https://doi.org/10.1016/j.jhazmat.2021.125052.

Godzik B., 1993: Heavy Metals Content in Plants from Zinc Dumps and Reference Areas. "Polish Botanical Studies", 5, s. 113-132.

Godzik B., red., 2015: Przyrodnicza i historyczna wartość Olkuskiego Okręgu Rudnego. W. Szafer Institute of Botany, Polish Academy of Sciences, Kraków.

Grodzińska K., Korzeniak U., Szarek-Łukaszewska G., Godzik B., 2000: Colonization of Zinc Mine Spoils in Southern Poland - Preliminary Studies on Vegetation, Seed Rain and Seed Bank. "Fragmenta Floristica et Geobotanica", T. 45, nr 1-2, s. 123-145.

Grodzińska K., Szarek-Łukaszewska G., 2002: Hałdy cynkowo-ołowiowe w okolicach Olkusza - przeszłość, teraźniejszość i przyszłość. „KOSMOS. Problemy nauk biologicznych", T. 51, nr 2, s. 127-138.

Gucwa-Przepióra E., Błaszkowski J., Kurtyka R., Małkowski Ł., Małkowski E., 2013: Arbuscular mycorrhiza of Deschampsia cespitosa (Poaceae) at Different Soil Depths in Highly Metal-Contaminated Site in Southern Poland. "Acta Societatis Botanicorum Poloniae", Vol. 82, no 4, s. 251-258. https://doi.org/10.5586/asbp.2013.033.

Gucwa-Przepióra E., Nadgórska-Socha A., Fojcik B., Chmura D., 2016: Enzymatic Activities and Arbuscular Mycorrhizal Colonization of Plantago lanceolata and Plantago major in a Soil Root Zone under Heavy Metal Stress. "Environmental Science and Pollution Research", Issue 23, s. 4742-4755. https://doi.org/10.1007/ s11356-015-5695-9.

Harańczuk R., Kompała-Bąba A., 2019: Changes in the Vascular Flora of a Postflotation Zinc-lead Ore Spoil Heap of the "Orzet Bialy" Mining and Smelting Works in Bytom (Silesian Upland) after 15 Years. "Acta Agrobotanica”, Vol. 72, no 1, 1762. https:// doi.org/10.5586/aa.1762.

Hu Y., Wang D., Wei L., Zhang X., Song B., 2014: Bioaccumulation of Heavy Metals in Plant Leaves from Yan'an City of the Loess Plateau, China. "Ecotoxicology and Environmental Safety", Vol. 110, s. 82-88. https://doi.org/10.1016/j.ecoenv.2014.08.021. Jędrzejczyk-Korycińska M., 2009: Obszary dawnej eksploatacji złóż cynkowo-ołowiowych - ich bogactwo florystyczne a możliwości ochrony. „Problemy Ekologii Krajobrazu", T. 24, s. 71-80. 
Jędrzejczyk-Korycińska M., Szarek-Łukaszewska G., 2020: Murawy galmanowe zagrożenia i możliwości ochrony - projekt „BioGalmany”. W: Buckler Mustard (Biscutella laevigata L.) an Extraordinary Plant on Ordinary Mine Heaps Near Olkusz. Pleszczotka górska (Biscutella laevigata L.) niezwykła roślina na zwykłych hałdach pogórniczych koło Olkusza. Red. G. Szarek-Łukaszewska. W. Szafer Institute of Botany, Polish Academy of Sciences, Kraków, s. 315-325.

Juda-Rezler K., Toczko B., red., 2016: Pyly drobne w atmosferze. Kompendium wiedzy o zanieczyszczeniu powietrza pyłem zawieszonym $w$ Polsce. Główny Inspektorat Ochrony Środowiska, Warszawa.

Kabata-Pendias A., 2001: Trace Elements in Soils and Plants. Third ed. CRC Press, Boca Raton-London-New York-Washington.

Kandziora-Ciupa M., Ciepał R., Nadgórska-Socha A., Barczyk G., 2013: A Comparative Study of Heavy Metal Accumulation and Antioxidant Responses in Vaccinium myrtillus L. Leaves in Polluted and Non-polluted Areas. "Environmental Science and Pollution Research", Vol. 20, Issue 7, s. 4920-4932. https://doi.org/10.1007/ s11356-012-1461-4.

Karczewska A., 2002: Metale ciężkie w glebach zanieczyszczonych emisjami hut miedziformy i rozpuszczalność. Wydawnictwo Akademii Rolniczej, Wrocław.

Kopcewicz J., Lewak S., red., 2002: Fizjologia roślin. Wydawnictwo Naukowe PWN, Warszawa.

Kováčik J., Dudáš M., Hedbavny J., Mártonfi P., 2016: Dandelion Taraxacum linearisquameum Does Not Reflect Soil Metal Content in Urban Localities. "Environmental Pollution", Vol. 218, s. 160-167. https://doi.org/10.1016/j.envpol.2016.08.030.

Kutrowska A., 2013: Roślinne transportery błonowe metali śladowych. „KOSMOS. Problemy nauk biologicznych", T. 62, nr 1, s. 105-113.

Lambers H., Stuart Chapin III F., Pons T., 2008: Plant Physiological Ecology. Springer, New York.

Maestri E., Marmiroli M., Visioli G., Marmiroli N., 2010: Metal Tolerance and Hyperaccumulation: Costs and Trade-offs between Traits and Environment. "Environmental and Experimental Botany", Vol. 68, Issue 1, s. 1-12. https://doi. org/10.1016/j.envexpbot.2009.10.011.

Markert B., 1992: Establishing of "Reference Plant" for Inorganic Characterization of Different Plant Species by Chemical Fingerprinting. "Water, Air, and Soil Pollution", 64, s. 533-538.

Markert B., Wünschmann S., Diatta J., Chudzińska E., 2012: Innowacyjna obserwacja środowiska - bioindykatory i biomonitoring: definicje, strategie i zastosowania. „Ochrona Środowiska i Zasobów Naturalnych”, 53, s. 15-145. 
Massa N., Andreucci F., Poli M., Aceto M., Barbato R., Berta G., 2010: Screening for Heavy Metal Accumulators amongst Autochtonous Plants in a Polluted Site in Italy. "Ecotoxicology and Environmental Safety", Vol. 73, s. 1988-1997. https://doi. org/10.1016/j.ecoenv.2010.08.032.

Muszyńska E., Hanus-Fajerska E., Ciarkowska K., 2020: Fitoremediacja jako antidotum na zanieczyszczenie środowiska. W: Buckler Mustard (Biscutella laevigata L.) an Extraordinary Plant on Ordinarymine Heaps near Olkusz. Pleszczotka górska (Biscutella laevigata L.) niezwykła roślina na zwykłych hałdach pogórniczych koło Olkusza. Red. G. Szarek-Łukaszewska. W. Szafer Institute of Botany, Polish Academy of Sciences, Kraków, s. 251-259.

Muszyńska E., Wiszniewska A., Hanus-Fajerska E., 2015: Roślinność terenów wzbogaconych w metaliczne pierwiastki śladowe jako unikatowe źródło bioróżnorodności. W: Różnorodność biologiczna - od komórki do ekosystemu. Funkcjonowanie roślin i grzybów. Środowisko - eksperyment - edukacja. Red. A. Bajguz, I. Ciereszko. Polskie Towarzystwo Botaniczne, Białystok, s. 63-77.

Nadgórska-Socha A., 2012: Poszukiwanie ciekawych gatunków roślin na terenach po eksploatacji rud cynkowo-ołowiowych. „Nowe Zagłębie”, nr 1, s. 31-33.

Nadgórska-Socha A., Ciepał R., 2009: Phytoextraction of Zinc, Lead and Cadmium with Silene vulgaris Moench (Garcke) in the Postindustrial Area. "Ecological Chemistry and Engineering", Vol. 16, no 7, s. 831-837.

Nadgórska-Socha A., Kandziora-Ciupa M., Ciepał R., 2015: Element Accumulation, Distribution, and Phytoremediation Potential in Selected Metallophytes Growing in a Contaminated Area. "Environmental Monitoring and Assessment", Vol. 187, 441. https://doi.org/10.1007/s10661-015-4680-6.

Nadgórska-Socha A., Kandziora-Ciupa M., Ciepał R., Barczyk G., 2016: Robinia pseudoacacia and Melandrium album in Trace Elements Biomonitoring and Air Pollution Tolerance Index Study. "International Journal of Environmental Science and Technology", Vol. 13, Issue 7, s. 1741-1752. https://doi.org/10.1007/s13762-016-1010-7.

Nadgórska-Socha A., Kandziora-Ciupa M., Trzęsicki M., Barczyk G., 2017: Air Pollution Tolerance Index and Heavy Metal Bioaccumulation in Selected Plant Species from Urban Biotopes. "Chemosphere", Vol. 183, s. 471-482. https://doi.org/10.1016/j. chemosphere.2017.05.128.

Nadgórska-Socha A., Ptasiński B., Kita A., 2013: Heavy Metal Bioaccumulation and Antioxidative Responses in Cardaminopsis arenosa and Plantago lanceolata Leaves from Metalliferous and Non-metalliferous Sites: a Field Study. "Ecotoxicology", Vol. 22, s. 1422-1434. https://doi.org/10.1007/s10646-013-1129-y. 
Oyuela Leguizamo M., Gómez W., Sarmiento M., 2017: Native Herbaceous Plant Species with Potential Use in Phytoremediation of Heavy Metals, Spotlight on Wetlands: a Review. “Chemosphere”, Vol. 168, s. 1230-1247. https://doi.org/10.1016/j. chemosphere.2016.10.075.

Pawłowska T., Błaszkowski J., Rühling A., 1996: The Micorrhizal Status of Plants Colonizing a Calamine Spoil Mound in Southern Poland. "Mycorrhiza", 6, s. 499-505.

Pehoiu G., Murărescu O., Radulescu C., Dulama I., Teodorescu S., Ştirbescu R., Bucurică I., Stanescu S., 2020: Heavy Metals Accumulation and Translocation in Native Plants Grown on Tailing Dumps and Human Health Risk. "Plant and Soil", Vol. 456, Issue 1-2, s. 405-424. https://doi.org/10.1007/s11104-020-04725-8.

Przedpełska E., Wierzbicka M., 2007: Arabidopsis arenosa (Brassicaceae) from a Leadzinc Waste Heap in Southern Poland - a Plant with High Tolerance to Heavy Metals. "Plant and Soil", Vol. 299, s. 43-53. https://doi.org/10.1007/s11104-007-9359-5.

Przepindowski Z., 2004: 170 lat Huty Metali Nieżelaznych “Szopienice” S.A. „Gazeta Wyborcza” z 30 listopada, s. 15.

Przewodnik po Zagłębiu Dąbrowskim, 1993. Reprint z 1939 roku. Muzeum Śląskie w Katowicach, Katowice.

Rai P., Panda L., 2014: Dust Capturing Potential and Air Pollution Tolerance Index (APTI) of Some Road Side Tree Vegetation in Aizawl, Mizoram, India: an IndoBurma Hot Spot Region. "Air Quality, Atmosphere, and Health", Vol. 7, no 1, s. 93-101. https://doi.org/10.1007/s11869-013-0217-8.

Remon E., Bouchardon J.-L., Le Guédard M., Bessoule J.-J., Conord C., Faure O., 2013: Are Plants Useful as Accumulation Indicators of Metal Bioavailability. "Environmental Pollution", Vol. 175, s. 1-7. https://doi.org/10.1016/j.envpol.2012.12.015.

Rogala D., Hajok I., Marchwińska-Wyrwał E., 2015: Narażenie mieszkańców Siemianowic Śląskich na pył zawieszony PM10 i metale ciężkie. „Problemy Higieny i Epidemiologii", Vol. 96, s. 427-436.

Romeh A., 2017: Risk Assessment of Heavy Metals Pollution at Zagazig University, Zagazig, Egypt. "International Journal of Environmental Science and Technology", Vol. 15, s. 1393-1410. https://doi.org/10.1007/s13762-017-1489-6.

Roo-Zielińska E., 2004: Fitoindykacja jako narzędzie oceny środowiska fizycznogeograficznego. Podstawy teoretyczne i analiza porównawcza stosowanych metod. IGiPZ PAN, Warszawa.

Rosmus D., 2013: Archeologiczne ślady wczesnośredniowiecznej technologii wytopu ołowiu - uwagi na temat współpracy interdyscyplinarnej archeologów, metalurgów i specjalistów w zakresie ochrony środowiska. W: Dzieje górnictwa - element europejskiego 
dziedzictwa kultury. Red. P.P. Zagożdżon, M. Madziarz. T. 5. Oficyna Wydawnicza Politechniki Wrocławskiej, Wrocław, s. 317-328.

Rostański A., 1997: Zawartość metali ciężkich $w$ glebie i roślinach $z$ otoczenia niektórych emitorów zanieczyszczeń na Górnym Śląsku. "Archives of Environmental Protection", Vol. 23, no 3-4, s. 181-189.

Rostański A., Nowak T., Jędrzejczyk-Korycińska M., 2015: Metalolubne gatunki roślin naczyniowych we florze Polski. W: Ekotoksykologia: rośliny, gleby, metale. Red. M. Wierzbicka. Wydawnictwa Uniwersytetu Warszawskiego, Warszawa, s. 175-189.

Rühling A., Tyler G., 1968: An Ecological Approach to the Lead Problem. "Botaniska Notiser", 121, s. 321-342.

Rybak A., 2002: Państwowe górnictwo galmanu na terenie Dąbrowy Górniczej w XIX wieku ze szczególnym uwzględnieniem strzemieszyckiego ośrodka górnictwa galmanu. Muzeum Miejskie „Sztygarka”, Dąbrowa Górnicza.

Rybak A., 2004: Ślady górnictwa kruszcowego na terenie Dąbrowy Górniczej i jej okolic. W: Archeologiczne $i$ historyczne ślady górnictwa i hutnictwa na terenie Dąbrowy Górniczej i okolic. Red. D. Rozmus. Księgarnia Akademicka, Kraków, s. 107-124.

Sawicka-Kapusta K., Zakrzewska M., Dudzik P., 2018: Zmiany zanieczyszczenia powietrza Stacji Bazowych ZMŚP w latach 2001-2014 na podstawie oceny zawartości metali ciężkich $i$ siarki $w$ porostach. W: Stan i przemiany środowiska przyrodniczego geoekosystemów Polski w latach 1994-2015 w oparciu o realizację programu Zintegrowanego Monitoringu Środowiska Przyrodniczego. Red. A. Kostrzewski, M. Majewski. Główny Inspektorat Ochrony Środowiska-Oficyna Drukarska Jacek Chmielewski, Warszawa, s. 417-449.

Sayo S., Kiratu J., Nyamato G., 2020: Heavy Metal Concentrations in Soil and Vegetables Irrigated with Sewage Effluent: A Case Study of Embu Sewage Treatment Plant, Kenya. "Scientific African”, Vol. 8, e00337. https://doi.org/10.1016/j.sciaf.2020.e00337.

Serbula S., Miljkovic D., Kovacevic R., Ilic A., 2012: Assessment of Airborne Heavy Metal Pollution Using Plant Parts and Topsoil. "Ecotoxicology and Environmental Safety", Vol. 76, s. 209-214. https://doi.org/10.1016/j.ecoenv.2011.10.009.

Shahid M., Dumat C., Khalid S., Schreck E., Xiong T., Niazi N.K., 2017: Foliar Heavy Metal Uptake, Toxicity and Detoxification in Plants: A Comparison of Foliar and Root Metal Uptake. "Journal of Hazardous Materials", Vol. 325, s. 36-58. https:// doi.org/10.1016/j.jhazmat.2016.11.063.

Simon E., Baranyai E., Braun M., Cserháti C., Fábián I., Tóthmérész B., 2014: Elemental Concentrations in Deposited Dust on Leaves along an Urbanization Gradient. "Science of the Total Environment", Vol. 490, s. 514-520. https://doi.org/10.1016/j. scitotenv.2014.05.028. 
Siwek M., 2008: Rośliny w skażonym metalami ciężkimi środowisku poprzemysłowym. Część I. Pobieranie, transport i toksyczność metali ciężkich (śladowych). „Wiadomości Botaniczne", 52, s. 7-22.

Skrynetska I., Ciepał R., Kandziora-Ciupa M., Barczyk G., Nadgórska-Socha A., 2018: Ecophysiological Responses to Environmental Pollution of Selected Plant Species in an Industrial Urban Area. "International Journal of Environmental Research", Vol. 12, Issue 2, s. 255-267. https://doi.org/10.1007/s41742-018-0088-9.

Skrynetska I., Karcz J., Barczyk G., Kandziora-Ciupa M., Ciepał R., Nadgórska-Socha A., 2019: Using Plantago major and Plantago lanceolata in Environmental Pollution Research in an Urban Area of Southern Poland. "Environmental Science and Pollution Research", Vol. 26, Issue 23, s. 23359-23371. https://doi.org/10.1007/ s11356-019-05535-x.

Skubała K., 2011: Vascular Flora of Sites Contaminated with Heavy Metals on the Example of Two Post-industrial Spoil Heaps Connected with Manufacturing of Zinc and Lead Products in Upper Silesia. "Archives of Environmental Protection", Vol. 37, no 1 , s. $57-74$.

Słomka A., Libik-Konieczny M., Kuta E., Miszalski Z., 2008: Metalliferous and Nonmetalliferous populations of Viola tricolor represent similar mode of antioxidative response. "Journal of Plant Physiology", Vol. 165, s. 1610-1619. https://doi. org/10.1016/j.jplph.2007.11.004.

Słysz A., Wierzbicka M.H., 2005: Przystosowania roślin Armeria maritima do wzrostu $w$ środowisku skażonym metalami ciężkimi. W: Obieg pierwiastków w przyrodzie. T. 3. Red. B. Gworek. Instytut Ochrony Środowiska, Warszawa, s. 629-636.

Stefanowicz A., Stanek M., Woch M., 2016: High Concentrations of Heavy Metals in Beech Forest Understory Plants Growing on Waste Heaps Left by Zn-Pb Ore Mining. "Journal of Geochemical Exploration", Vol. 169, s. 157-162. https://doi.org/10.1016/j. gexplo.2016.07.026.

Szarek-Gwiazda E., 2016: Metale ciężkie. W: Zbiornik wodny Dobczyce. Red. T. Sądag i in. Regionalny Zarząd Gospodarki Wodnej, Kraków, s. 153-158.

Szarek-Łukaszewska G., 2009: Vegetation of Reclaimed and Spontaneously Vegetated $\mathrm{Zn}$-Pb Mine Wastes in Southern Poland. "Polish Journal of Environmental Studies", Vol. 18, s. 717-733.

Szarek-Łukaszewska G., Grodzińska K., 2008: Naturalna roślinność w rejonach starych zwałowisk odpadów po górnictwie Zn-Pb w okolicy Bolesławia i Bukowna (region śląsko-krakowski; południowa Polska). „Przegląd Geologiczny”, Vol. 56, no 7, s. $528-531$. 
Szarek-Łukaszewska G., Grodzińska K., 2011: Grasslands of Zn-Pb Post-mining Area (Olkusz Ore-Bearing Region, S Poland). "Polish Botanical Journal", Vol. 56, s. 245-260.

Szarek-Łukaszewska G., Niklińska M., 2002: Concentration of Alkaline and Heavy Metals in Biscutella laevigata L. and Plantago lanceolata L. Growing on Calamine Spoils (S. Poland). "Acta Biologica Cracoviensia. Series Botanica”, Vol. 44, s. 29-38.

Szarek-Łukaszewska G., Nowak T., Grodzińska K., Kapusta P., Godzik B., 2015: Charakterystyka przyrodnicza obszarów metalonośnych w różnych rejonach Polski. W: Ekotoksykologia: rośliny, gleby, metale. Red. M. Wierzbicka. Wydawnictwa Uniwersytetu Warszawskiego, Warszawa, s. 163-174.

Świsłowski P., Marciniak M., Rajfur M., 2017: Wpływ warunków prowadzenia eksperymentu na wyniki badań biomonitoringowych $z$ zastosowaniem mchów. „Proceedings of ECOpole", Vol. 11, no 1, s. 313-323. https://doi.org/10.2429/proc.2017.11(1)033.

Tokarska-Guzik B., Rostański A., Klotz S., 1991: Roślinność hałdy pocynkowej w Katowicach-Wetnowcu. „Acta Biologica Silesiana”, T. 19, s. 94-101.

Traczewska T., 2011: Biologiczne metody oceny skażenia środowiska. Oficyna Wydawnicza Politechniki Wrocławskiej, Wrocław.

Walker C.H., Hopkin S.P., Sibly R.M., Peakall D.B., 2002: Podstawy ekotoksykologii. Red. wyd. pol. P. Migula. Wydawnictwo Naukowe PWN, Warszawa.

Wierzbicka M., 2002: Przystosowania roślin do wzrostu na hałdach cynkowo-ołowiowych okolic Olkusza. „KOSMOS. Problemy nauk biologicznych”, T. 51, nr 2, s. 139-150.

Wierzbicka M., Rostański A., 2002: Microevolutionary Changes in Ecotypes of Calamine Waste Heap Vegetation near Olkusz, Poland: a Review. „Acta Biologica Cracoviensia. Series Botanica", Vol. 44, s. 7-19.

Wikarek-Paluch E., Rosik-Dulewska C., 2020: Biodostępność wybranych zanieczyszczeń $w$ gruntach zdegradowanych chemicznie. Instytut Podstaw Inżynierii Środowiska Polskiej Akademii Nauk, Zabrze.

Włodarz B., 2020: Historia olkuskiego rejonu wydobycia rud cynkowo-ołowiowych i obszarów występowania Biscutella laevigata L. W: Buckler Mustard (Biscutella laevigata L.) an Extraordinary Plant on Ordinarymine Heaps near Olkusz. Pleszczotka górska (Biscutella laevigata L.) niezwykła roślina na zwykłych hałdach pogórniczych koło Olkusza. Red. G. Szarek-Łukaszewska. W. Szafer Institute of Botany, Polish Academy of Sciences, Kraków, s. 41-52.

Woch M., Kapusta P., Stefanowicz A., 2016: Variation in Dry Grassland Communities along a Heavy Metals Gradient. "Ecotoxicology", Vol. 25, s. 80-90. https://doi. org/10.1007/s10646-015-1569-7.

Wójcik A., Tukendorf A., 1995: Strategia unikania stresu w odporności roślin na metale ciężkie. „Wiadomości Botaniczne”, T. 39, nr 3-4, s. 33-40. 
Wójcik M., Dresler S., Sugier P., Stanisławski G., Hanaka A., Krupa Z., Tukiendorf A., 2015a: Roślinność spontanicznie zasiedlająca składowiska odpadów cynkowo-ołowiowych - różnorodność gatunkowa oraz mechanizmy adaptacji. W: Różnorodność biologiczna - od komórki do ekosystemu. Funkcjonowanie roślin i grzybów. Środowisko eksperyment - edukacja. Red. A. Bajguz, I. Ciereszko. Polskie Towarzystwo Botaniczne, Białystok, s. 51-63.

Wójcik M., Dresler S., Tukiendorf A., 2015b: Physiological Mechanisms of Adaptation of Dianthus carthusianorum L. to Growth on a Zn-Pb Waste Deposit - the Case of Chronic Multi-metal and Acute Zn Stress. "Plant and Soil", Vol. 390, s. 237-250. https://doi.org/10.1007/s11104-015-2396-6.

Wójcik M., Sugier P., Siebielec G., 2014: Metal Accumulation Strategies in Plants Spontaneously Inhabiting $\mathrm{Zn}-\mathrm{Pb}$ Waste Deposits. "Science of Total Environment", Vol. 487, s. 313-322. https://doi.org/10.1016/j.scitotenv.2014.04.024.

Wysocki C., 2019: Funkcjonowanie szaty roślinnej w warunkach miejskich. The Functioning of Plant Cover in Urban Conditions. „Przegląd Geograficzny”, T. 91, z. 3, s. 421-434. https://doi.org/10.7163/PrzG.2019.3.7.

Yadav S., 2010: Heavy Metals Toxicity in Plants: an Overview on the Role of Glutathione and Phytochelatins in Heavy Metal Stress Tolerance of Plants. "South African Journal of Botany”, Vol. 76, Issue 2, s. 167-179. https://doi.org/10.1016/j.sajb.2009.10.007.

Załęcka R., Wierzbicka M., 2002: The Adaptation of Dianthus carthusianorum L. (Caryophyllaceae) to Growth on a Zinc-lead Heap in Southern Poland. "Plant and Soil", Vol. 246, no 2, s. 249-257.

Zarzycki K., Trzcińska-Tacik H., Różański W., Szeląg Z., Wołek J., Korzeniak U., 2002: Ecological Indicator Values of Vascular Plants of Poland. Ekologiczne liczby wskaźnikowe roślin naczyniowych Polski. W. Szafer Institute of Botany, Polish Academy of Sciences, Kraków.

Zimny H., 2006: Ekologiczna ocena stanu środowiska: bioindykacja i biomonitoring. Agencja Reklamowo-Wydawnicza Arkadiusz Grzegorczyk, Warszawa.

Aleksandra NAdgórska-Socha - dr hab. nauk biologicznych, prof. UŚ, absolwentka Wydziału Biologii i Ochrony Środowiska Uniwersytetu Śląskiego. Pracowała w Katedrze Ekologii, prowadziła badania dotyczące ekofizjologii roślin i wpływu metali ciężkich na rośliny, oceny zanieczyszczenia środowiska za pomocą bioindykatorów, funkcjonowania ekosystemu glebowego w warunkach zanieczyszczenia, ekologii miasta oraz jakości produktów roślinnych z upraw ekologicznych i konwencjonalnych. W pracy doktorskiej pt. Ekofizjologiczne badania wybranych populacji Silene vulgaris rosnacych 
$w$ warunkach skażenia metalami ciężkimi prowadziła badania nad fizjologiczną odpowiedzią metalofita - lepnicy rozdętej, na zanieczyszczenie gleby metalami ciężkimi. Cykl artykułów pt. Wskaźniki ekofizjologiczne u wybranych gatunków roślin z terenów miejskich o zróżnicowanym stopniu zanieczyszczenia stał się podstawą do uzyskania stopnia doktora habilitowanego. Obecnie jest liderem Zespołu Ekologii w Instytucie Biologii, Biotechnologii i Ochrony Środowiska Wydziału Nauk Przyrodniczych UŚ. $\mathrm{Na}$ co dzień stara się łączyć pasję naukową z przekazywaniem i popularyzacją wiedzy biologicznej, jest certyfikowanym tutorem i pełni funkcję dyrektora kierunku: biologia, biotechnologia i ochrona środowiska. 